\title{
Profesní aktérství začínajících učitelů v základních školách ${ }^{1}$
}

\author{
Michaela Píšová, Světlana Hanušová \\ Masarykova univerzita, Pedagogická fakulta
}

\begin{abstract}
Abstrakt: Téma aktérství (agency), přesněji řečeno profesního aktérství začínajících učitelů, se vynořilo $v$ rámci výzkumu drop-outu a jeho determinant u této profesní skupiny. K nejvýznačnějším zjištěním, která tento výzkum přinesl, patří zásadní význam determinant na úrovni školy, zejména kultury a klimatu školy, spolupráce s kolegy a vedením školy. Pro začínající učitele jsou klíčové nejen pomoc a podpora (včetně kvalitního mentoringu), ale rovněž uznání vedením školy i kolegy a prostor pro samostatné rozhodování a jednání, tj. profesní aktérství. $V$ tomto textu se zaměřujeme na projevy profesního aktérství začínajících učitelů a na faktory na úrovni školy, které jej ovlivňují. Po vymezení pojmu aktérství přinášíme výsledky kvalitativní analýzy rozhovorů se začínajícími učiteli. V analýze jsme vycházeli z Gollerovy koncepce aktérství jako dispozice i jako jednání, které vede k určitým výsledkům. Dospěli jsme k závěru, že u začínajících učitelů lze hovořit o značné miřre profesního aktérství, jehož forma je výrazně ovlivňována prostředím školy, vedením školy a kolegy.
\end{abstract}

Kličová slova: začínající učitel, aktérství, škola, vedení školy, kolegové

\section{Professional Agency in Novice Teachers at Primary and Lower-Secondary Schools}

Abstract: The theme of agency, more precisely the professional agency of novice teachers, emerged within our research into drop-out and its determinants in this professional group. The most important findings of this research included the key significance of the determinants at the school level, especially the influence of school culture and climate, cooperation with colleagues and leadership. Not only assistance and support (including high-quality mentoring) but also recognition by the head teacher and colleagues, and space for independent decision-making and acting, known as professional agency, proved to be crucial for novice teachers. In this text, we focus on the manifestations of professional agency of novice teachers and on the factors at the school level that influence it. After defining the concept of agency, we present the results of a qualitative analysis of interviews with novice teachers. We employed Goller's conception of agency as human agency and agentic action that leads to certain outcomes as a basis of our analysis. We came to the conclusion that it is possible to identify a great deal of professional agency in novice teachers, the form of which is strongly influenced by the school environment, school leadership and colleagues.

Keywords: novice teacher, agency, school, leadership, colleagues

1 Text vznikl s podporou Grantové agentury ČR v rámci projektu Jaký význam má kontext: objektivní determinanty socializace začínajících učitelů (GA15 12956S). distribution, and reproduction in any medium, provided the original author and source are credited. 
86 Společenské, ekonomické a politické výzvy 21. století kladou na školy řadu požadavků. Vzdělávací politika u nás i jinde ve světě (srov. Goodson, 2003; Biesta, Priestley, \& Robinson, 2015; aj.) v souvislosti s těmito změnami definuje školy jako učíci se organizace, v nichž učitelé aktivně přispívají k reformování vlastního profesního působení i jeho podmínek. Do centra pozornosti pedagogické teorie i výzkumu se proto v posledních letech dostává v zahraničí pojem aktérství (agency; např. Billett, 2011; Eteläpelto et al., 2013; Harteis \& Goller, 2014; Priestley, Biesta, \& Robinson, 2015; Goller, 2017; Paloniemi \& Goller, 2017; Vähäsantanen et al., 2017).

Často se - zejména $v$ médiích a v širši veřejnosti - setkáváme s očekáváním, že hybateli žádoucí změny (ve) vzdělávání budou progresivní mladí (tj. začínající) učitelé. Zároveň je ovšem známo, že profesní socializace začínajících učitelů je velmi náročný a citlivý proces - právě novicové jsou profesní skupinou, která je nejvíce ohrožena tzv. drop-outem, odchodem z profese či přechodem do jiné školy (Píšová \& Hanušová, 2016). Tato výzkumná studie se pokusí naznačit odpovědi na otázky, jakou roli hraje profesní aktérství v procesech profesní socializace a v rozhodování začínajících učitelů o jejich budoucnosti ve školství a jak je jejich aktérství ovlivněno prostředím školy, především kolegy $v$ učitelském sboru a vedením školy.

\section{Aktérství (agency) - vymezení pojmu}

Množství různých pojmů používaných v diskusi o aktérství (agency) reflektuje mnohoaspektovost tohoto fenoménu. Např́klad $v$ anglicky psaných zdrojích se setkáme s pojmy human agency, life-course agency, professional agency, work agency, creative agency, epistemological agency, relational agency, bounded agency, transformational agency, dialogical agency, agency beliefs a identity agency, další významově blízké pojmy zahrnují innovative work behaviour, reflection, proactivity, enterpreneurship, intrapreneurship, grit, feedback seeking apod. Autor uvedeného výčtu pojmů Goller (2017) s oporou o text Eteläpeltové (2017) upozorňuje, že zde mohou do hry vstupovat nejen individuální preference jednotlivých odborníků, ale také lingvistické důvody. Některé jazyky (např. němčina) totiž ve svém slovníku specifický termín pro agency nemají, zatímco jiné (kupř. finština) s ekvivalentním slovem běžně pracují. Domnívá se, že toto může být jeden $z$ důvodů, proč je $v$ německy psaných odborných textech agency zmiňována jen velmi zřídka, i když pojednávají o fenoménu profesního rozhodování a na něm založeného jednání. V českém pedagogickém diskurzu se pracuje s pojmy aktérství a aktérské jednání, zatím se ale objevují rovněž poměrně sporadicky (např. ve spojení s autonomií Ježek, 2014; Mareš \& Mareš, 2014; v monografii o sebepojetí učitele Lukášová, 2015; Gavora, 2016; Walterová, 2016).

Pojem aktérství v obecné rovině vychází z myšlenky, že zaměstnanci jsou v pracovním kontextu aktivními a odpovědnými aktéry, jejichž aktérské jednání spočívá v aktivní spoluúčasti: zaujímají stanoviska, činí rozhodnutí a předkládají návrhy, ovlivňují dění (Vähäsantanen et al., 2017). Tím přispívají k produktivním pracovním 
postupům, inovativním řešením problémů a k smysluplnému profesnímu rozvoji na úrovni jedince i organizace (srov. Harteis \& Goller, 2014). Jinými slovy, jedinci i skupiny jedinců jako aktéři aktivně řídí své profesní životy a utvářejí organizaci, $v$ níž působí (Emirbayer \& Mische, 1998; Goller, 2017).

\subsection{Pojetí aktérství v různých společenských disciplínách}

Zatímco v pedagogické teorii a výzkumu se pojem aktérství etabluje až v posledních letech, v jiných společenskovědních oborech je rozpracováván již po dlouhou dobu. Eteläpeltová et al. (2013) i Goller (2017) však v přehledových studiích konstatovali, že explicitní a konsenzuální definice pojmu napříč vědními obory a výzkumnými poli neexistuje, jedná se spíše o volné asociace s aktivním usilováním, přijímáním iniciativy či vlivu na vlastní životní situace. Kořeny pojmu aktérství je třeba hledat v sociologii (Giddens, 1984; Emirbayer \& Mische, 1998; Archer, 2003), ale pojem je ukotven i v antropologii (Ahearn, 2001; Holland et al., 1998), psychologii (Bandura, 2001, 2006), genderových (např. Clegg, 2006) a v neposlední řadě v politologických studiích.

Eteläpeltová et al. (2013) do své přehledové studie zahrnuly sociologické, psychologické, pedagogické a genderové studie. Na základě analýzy identifikovaly čtyři základní linie diskuse spojené s pojmem aktérství: společenskovědní (social science discourse, zejména sociologický diskurz), poststrukturální diskuse (post-structural discussions), výzkum sociokulturního učení (socio-cultural learning research) a pojetí spojené s výzkumem identity a životního běhu (identity and life-course).

V sociologickém diskurzu je pojem aktérství extenzivně teoretizován v kontextu dlouhodobě probíhající debaty struktura-jednání (structure-agency debate), tj. diskuse o individualistickém versus holistickém vysvětlení sociálních jevů. V jejím průběhu vstupují na scénu další pojmy a teorie, které mají ambici přerámovat tuto debatu, viz např́klad Bourdieu (1977) a pojem habitus, Giddensova (1984) teorie strukturace či realistická sociální teorie Archerové (1995; srov. Hájek, 2007).

Poststrukturální diskuse jsou vedeny akcentem na jazyk, který formuje a zároveň konstruuje sociální realitu. Radikální poststrukturalisté proto takřka výlučně konceptualizují aktérství jako diskurzivní a kolektivní fenomén, zatímco umírněnější je chápou jako „žitou zkušenost v oblasti sociálních vztahů a vlastní schopnosti sebereflexe a jednání“ (Eteläpelto et al., 2013, s. 60), a to v sociálně konstruovaném světě.

Sociokulturní diskusi lze charakterizovat jako aktérství jedinců v sociálním světě, jež nelze oddělit od jejich subjektivity a profesní identity (např. Holland et al., 2003). Projevy aktérství přitom mohou zahrnovat rozhodnutí účastnit se ustavených praktik či je odmítnout (srov. Billett \& Somerville, 2004).

Biografický výzkum (life-course research) pak pojímá aktérství zejména ve vztahu k rozhodování a snahám, jež ovlivňují životní běh jedinců. Aktérské jednání ovšem neprobíhá v sociálním vakuu, ale je ukotveno v historických a sociálních okolnostech.

Na základě analýz je možné konstatovat, že aktérství je někdy vymezováno pouze jako racionální a intencionální jednání, jindy je pojímáno v temporální perspektivě, 
88 pokrývá ontogenetický vývoj jedince a zahrnuje různé typy vztahů se světem (diskurzivní, praktické, tělesné; discursive, practical, embodied; Archer, 2000, 2003). Časovou perspektivu aktérství zdůrazňují například Emirbayer a Mischeová (1998), kteři konfiguraci minulých vlivů, orientace na budoucnost a zaujetí současností tematizují jako tři dimenze aktérství: dimenzi iterační (iterational), projektivní (projective) a dimenzi prakticko-evaluativní (practical-evaluative) (Emirbayer \& Mische, 1998, s. 963). Tito významní sociologové promítají do svého vymezení pojmu temporálně relační kontext aktérského jednání, které probíhá v různých strukturálních prostředích $\mathrm{a} v$ interakci s měnící se historickou situací směřuje $\mathrm{k}$ reprodukci či transformaci těchto struktur² (tamtéž, s. 970).

Eteläpeltová et al. (2013) ve své přehledové studii dále věnují pozornost rozdílům v pojetí aktérství, které se týkají vztahu mezi jeho individuálními a sociálními/kontextovými aspekty. Různá pojetí jsou rozprostřena na ose mezi úplným analytickým oddělením těchto aspektů až $\mathrm{k}$ jejich neoddělitelnosti, přičemž v druhém případě je vliv kontextu někdy vnímán jako slabý, jindy jako silný. Autorky se při vymezení aktérství přiklánějí k subjektově zaměřené sociokulturní perspektivě (subject-centred socio-cultural perspective), v jejímž rámci jsou individuální aktérství a sociální kontext analyticky oddělené, ale vzájemně konstitutivní a vysoce vzájemně závislé. Jejich konceptualizace je v současnosti poměrně vlivná, proto zde uved'me její nejdůležitější charakteristiky:

- Profesní aktérství je prováděno a prokazováno, když profesní subjekt a/nebo komunity uplatňují vliv, volí z možností a zaujímají postoje zpưsobem, který ovlivňuje jejich práci a/nebo jejich profesní identity.

- Profesní aktérství je vždy prováděno s určitým záměrem a v rámci jistých (historicky formovaných) sociokulturních a materiálních podmínek, a je jimi omezeno i zajištěno.

- Uplatňování profesního aktérství je úzce spjato s profesní identitou jedinců zahrnující jejich profesní a etické závazky (commitment), ideály, motivaci, zájmy a cíle.

- Jedinečné (pracovní) zkušenosti profesního subjektu, jeho znalosti a kompetence fungují jako individuální rozvojové afordance (možnosti) a zdroje pro praktikování profesního aktérství.

- Profesní aktérství je potřebné zejména pro rozvoj vlastní práce jedince a rozvoj pracovních společenství, pro vyvíjení tvưrčích iniciativ. Je rovněž potřebné pro profesní učení a pro reformování profesní identity v měnících se pracovních praktikách. (Eteläpelto et al., 2013, s. 62)

Přehledová práce Gollera (2017) analyzuje hlavně studie realizované v rámci sociálně kognitivní psychologie, biografického výzkumu a v oblasti teoretizace proaktivity ve výzkumu organizačního chování. Shrňme zde závěry, ke kterým autor na základě analýzy dospěl:

2 Volně podle: ,.... the temporally constructed engagement by actors of different structural environments - the temporal-relational contexts of action - which, through the interplay of habit, imagination, and judgement, both reproduces and transforms those structures in interactive response to the problems posed by changing historical situations. " (Emirbayer \& Mische, 1998, s. 970) 
- Aktérství je chápáno jako proces, v němž jedinci na základě jasné představy o požadovaném budoucím stavu věcí formulují cíl a převádějí tento cíl do konkrétnějších dílčích cílů, vytvoří realizovatelný akční plán a uplatní aktérské jednání, jež vede k materializaci požadovaného budoucího stavu. Tento proces předpokládá či vyžaduje, aby jedinci vykazovali aktérské dispozice a měli schopnost skutečně projít celým procesem, tj. uskutečnit konkrétní jednání, dále aby byli přesvědčeni o těchto schopnostech a aby jejich jednání skutečně vedlo k očekávané změně.

- V každé ze tří analyzovaných vědních oblastí byly diskutovány prediktory aktérského jednání, nikoli však ve vzájemné shodě. Zvláště silné empirické důkazy se týkají tří prediktorů, a to (a) sebepoznání a schopnosti seberegulace, (b) přesvědčení o schopnosti sebeřizení (control beliefs) a (c) odpovídajících osobnostních charakteristik pro aktérské jednání.

- Ačkoli je aktérství v rámci analyzovaných výzkumných oblastí diskutováno především z individuální perspektivy, je zde zároveň shoda, že sociální kontext rovněž silně determinuje uplatnění aktérského jednání. Informativní v tomto směru byl zejména výzkum organizačního chování, který naznačil, že mezi specifické situační charakteristiky, jež podporují či brzdí proaktivní jednání, patři rízení pracovních procesů, styl leadershipu, podpora spolupracovníkủ a pracovní stresory.

- Aktérství a aktérské jednání je konceptualizováno jako pozitivní fenomén, který se vztahuje $\mathrm{k}$ dosahování žádoucích cílů. Aktérské jednání přitom mưže směřovat $\mathrm{k}$ individuálním cílům, ale i $\mathrm{k}$ pozitivním proměnám struktur.

Ačkoli pro účely našeho výzkumu jsou výstupy obou přehledových studií informativní, nelze si nepovšimnout faktu, že obě staví na analýze především subjektově orientovaných prací. Stranou zájmu zde tudíž zůstává rozsáhlá oblast objektově orientované konceptualizace aktérství, tj. - bez nároku na úplnost - konceptualizace $v$ rámci kulturně-historické teorie činnosti (cultural-historical activity theory; Leontiev, 1978; Engeström, 1987), oblastí relační sociologie, teorie organizačního učení (Lazarová et al., 2012) či šířeji koncipované ekologické koncepce aktérství (Priestley et al., 2015) apod. Je však třeba mít spolu s Biestou et al. (2015) na paměti, že socializační procesy jsou do značné míry závislé na receptivitě jedince, jeho zájmu a schopnosti aktivně interpretovat kontextové normy, praktiky a interakce. V tomto smyslu jsou procesy vyjednávání mezi sociálními a osobními přínosy relačního charakteru a souvisí s relačním aktérstvím jedince. Edwardsová (2005, s. 170) relační aktérství vymezuje jako „schopnost sblížit vlastní myšlení a jednání s myšlením a jednáním druhých za účelem interpretování problémů praxe a odpovídání na ně““3. Do vyjednávání ovšem vstupují obě strany, tudíž míra, v níž lze individuální aktérství otevřeně uplatnit, se může lišit (viz též pojem omezené aktérství - bounded agency; Evans, 2002).

\subsection{Východisko pro výzkumnou studii: konceptualizace aktérství podle Gollera (2017)}

Dosavadní diskuse mohla postihnout mnohoaspektovost pojmů aktérství a aktérské jednání jen v nejstručnější podobě. Pro účely výzkumu aktérství začínajících učitelů

3 ,... a capacity to align one's thought and actions with those of others in order to interpret problems of practice and to respond to those." (Edwards, 2005, s. 170) 
90 bylo ovšem nezbytné formulovat pracovní definici pojmu i jeho operační rámec. Vzhledem $\mathrm{k}$ cílům našeho šetření jsme jako vhodné vymezení přijali pojetí aktérství prezentované Gollerem (2017, s. 86-88). Jedná se o individuální pojetí aktérství, které se snaží o propojení dvou perspektiv identifikovaných $v$ jeho přehledové studii. První z nich konceptualizuje aktérství jako dispozici, resp. osobnostní rys, který umožňuje jedincům činit volby a na jejich základě jednat. Implicitně tedy předpokládá, že se jedinci liší v míre, v jaké jsou schopni přejímat kontrolu nad vlastním životem, tedy že jsou „aktérsky“, resp. „ne-aktérsky“ (agentic versus non-agentic individuals) disponováni. Druhá perspektiva je činnostně orientovaná, pojímá aktérství jako něco, co jedinci „dělaji““ - zabývá se tedy záměrnými volbami a především jednáním. Goller $(2017$, s. 87) tyto dvě perspektivy v koncepčním rámci označuje jako human agency a agentic action, což překládáme jako aktérské dispozice a aktérské jednání. Konsekvence, které z aktérského jednání plynou, pak jsou označeny jako výsledky aktérského jednání (outcomes). Z grafického znázornění na obrázku 1 je zřejmé, že koncepční rámec samozřejmě zahrnuje i kontext aktérství a aktérského jednání jedince, a to jak sociokulturní, tak materiální (socio-cultural / material context).

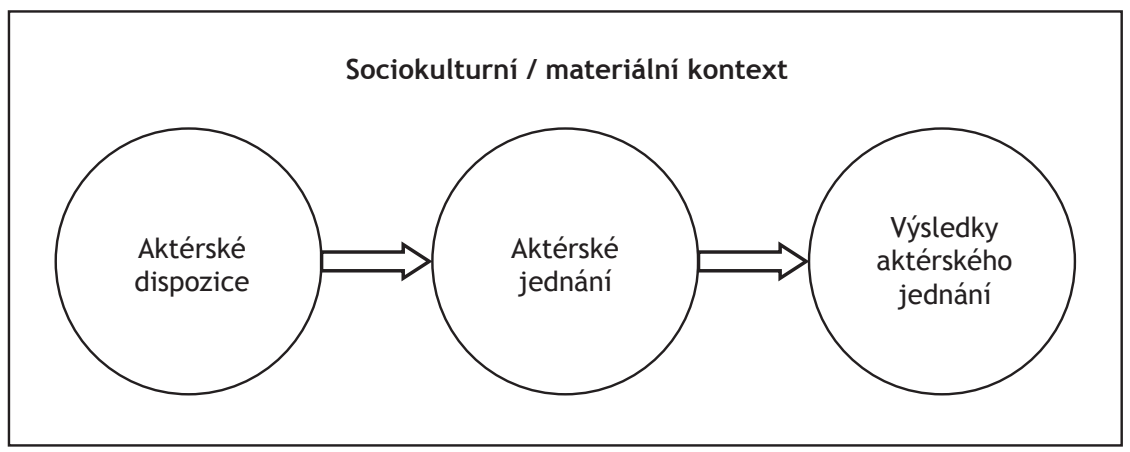

Obrázek 1 Koncepční rámec aktérství podle Gollera $(2017$, s. 87)

S koncepčním rámcem je spojena pracovní definice pojmu aktérství, jež je chápáno

„jako hybná síla vedoucí k zapojení jedince do aktérských akcí v pracovních kontextech. Pracovní aktérství je vymezeno jako dispozice / schopnost a tendence činit záměrné volby, iniciovat jednání založené na těchto volbách a rídit sebe i prostředí v pracovních kontextech."4 (Goller, 2017, s. 91)

4 ,.... work agency is understood as the main driving force behind an individual's engagement in agentic actions in work contexts. Work agency will be defined as the capacity and tendency to make intentional choices, to initiate actions based on these choices, and to exercise control over the self and the environment in work-related contexts." (Goller, 2017, s. 91) 
Co se týče výsledků, je aktérské jednání spojováno s řadou různých efektů. Různá pojetí je formulují podle svého zaměření, nicméně obecně lze říci, že se jedná o změny pozitivní. Velmi často je aktérství dáváno do souvislosti s profesním rozvojem a učením jedince, komunity či instituce, dále je spojováno se zvyšováním kvality pracovních procesů, ale také s kariérou jedince, jeho zdravotním stavem apod. Aktérství zaměřené na dosažení žádoucí změny bývá označováno jako transformační aktérství (transformative/transformational agency, Vähäsantanen et al., 2017).

Profesní aktérství se nicméně může projevovat i způsoby, které jsou méně proaktivní a rozvojové, např. reprodukováním pracovních praktik a resistencí vưči změně (Priestley et al., 2015), může tak vlastně změně bránit (Hökkä \& Eteläpelto, 2014). Konflikt silného individuálního aktérství a organizačního tlaku na změnu může vést k pasivitě či odporu (tzv. resisting agency, např. Billett, 2011). Priestly et al. (2015) dokonce používají termín destruktivní aktérství (destructive agency) pro neprofesionální jednání, které poškozuje zájmy žáků, kolegů či školy, nebo je morálně neobhajitelné. Silné individuální aktérství zaměřené na změnu ovšem může být v tradiční/ konzervativní organizaci rovněž vnímáno jako škodlivé (Goller, 2017). Pro náš výzkum je proto důležité zvažovat všechny projevy aktérství včetně těch, které přinášejí z hlediska školy jako organizace nežádoucí výsledky, tj. včetně pasivity, ne-jednání či dokonce odchodu ze školství.

\section{Výzkumné šetření}

\subsection{Kontext a cíle výzkumu}

V letech 2015-2017 jsme realizovali výzkumné šetření zacílené na problematiku profesní socializace začínajících učitelů a jejich vnímání toho, jaké zkušenosti spojují se svým rozhodnutím zůstat ve škole, ve které zahajují kariéru, změnit školu či učitelskou profesi opustit a profesně se uplatnit jinde (Hanušová et al., 2017). Výzkum byl koncipován jako explanační sekvenční smíšený design (explanatory sequential design; Creswell \& Plano Clark, 2011), jehož dominantní komponentou bylo kvantitativní dotazníkové šetření (380 začínajících učitelů ze základních škol v šesti krajích České republiky), na něž navazovala kvalitativní část realizovaná formou polostrukturovaných rozhovorů (20 učitelek), které blíže explorovaly kontext profesního vývoje a rozhodování začínajících učitelů o vlastní profesní perspektivě. V rámci výzkumného šetření, jehož výsledky jsou publikovány v monografii Hanušové et al. (2017), se vynořila významná determinanta setrvání začínajících učitelů ve škole, totiž možnost ovlivňovat dění ve škole a činit vlastní rozhodnutí. Proto jsme se rozhodli realizovat sekundární analýzu, při níž jsme se zaměřili výhradně na profesní aktérství začínajících učitelů v souvislosti s jejich působením v učitelském sboru.

Cílem tohoto navazujícího šetření bylo zjistit, jak začínající učitelé vypovídají o svých aktérských dispozicích a o aktérském jednání, jaké jsou případně výsledky tohoto jednání a jak mladí učitelé vnímají vliv prostředí školy, zejména kolegů 
92 v učitelském sboru a vedení školy, na své profesní aktérství. Na rozdíl od původního výzkumu jsme se spíše než na souvislosti s drop-outem zaměřovali právě na pưsobení prostředí školy a spolupráci v učitelském sboru.

Na základě výše uvedených teoretických východisek jsme stanovili následující výzkumné otázky:

V01. Projevovaly se ve výpovědích začínajících učitelů aktérské dispozice?

V02. Jak vypovídali začínající učitelé o vlastním aktérském jednání?

V03. Jak vypovídali začínající učitelé o výsledcích svého aktérského jednání?

V04. Jak vnímali začínající učitelé vliv prostředí (školy jako organizace) na své aktérství?

\subsection{Zkoumaný soubor}

Pro analýzu profesního aktérství jsme využili transkripty rozhovorů z výše popsaného výzkumného šetření. Jednalo se o 20 rozhovorů s učitelkami (všechny respondentky byly ženy) na počátku profesní dráhy z Jihomoravského, Moravskoslezského a Pardubického kraje. Délka praxe respondentek na počátku výzkumného šetření, tedy na podzim 2015, nepřesáhla tři roky (za začínajícího učitele jsme považovali učitele do tří let praxe, bez ohledu na to, zda během těchto tří let změnil školu). Při výběru respondentů jsme nejprve oslovili učitele, kteří se účastnili dotazníkového šetření, prostřednictvím osobního e-mailu, který nám dobrovolně poskytli. Pro účely kvalitativní fáze výzkumu jsme na základě náhodného výběru kontaktovali prvních 40 učitelů a následně jsme v př́padě odmítnutí či absence odpovědi oslovovali další učitele v pořadí, dokud jsme nezískali požadovaný počet 20 kladných odpovědí - úspěšnost při získávání učitelů pro rozhovor činila $15 \%$. Tato poměrně nízká úspěšnost nepochybně ovlivnila výsledné složení souboru respondentek (tabulky 1 a 2 ) a je třeba ji chápat jako určitý limit výzkumu. Vzhledem $\mathrm{k}$ tomu, jak malé procento oslovených projevilo ochotu rozhovor poskytnout, jsou rizika složení souboru obdobná rizikủm u samovýběru: získali jsme motivovanější, pravděpodobně ve škole spokojenější a zřejmě i z hlediska profesního aktérství vyhraněnější učitelky. Na druhé straně, nevybírali jsme z celé populace, ale ze souboru účastníků kvantitativního šetření, jehož parametry jsou známy (Hanušová et al., 2017, s. 106-112), což rizika samovýběru do značné míry kompenzuje.

Rozhovory byly realizovány od dubna do června 2017, většinou formou osobního setkání, v několika případech ale i jako videokonference (s využitím služby Skype). Průměrná délka rozhovoru byla 31 minut (min. 22 a max. 78 minut).

Tabulka 1 Popis zkoumaného souboru

\begin{tabular}{ll}
\hline$N=20$ & \\
\hline Pohlaví & Ženy: $20(100 \%)$ \\
Průměrný věk & $28,4(S D=5,3 ;$ min. 24, max. 44$)$ \\
Délka praxe & 17,1 měsíce $(S D=6,8 ;$ min. 8, max. 31) \\
\hline
\end{tabular}


Tabulka 2 Aprobace respondentek

\begin{tabular}{lll}
\hline Učitelka & Aprobace & \\
\hline U1 & anglický jazyk & 1. stupeň ZŠ \\
U2 & 1. stupeň ZŠ & \\
U3 & český jazyk & občanská výchova \\
U4 & anglický jazyk & francouzský jazyk \\
U5 & fyzika & občanská výchova \\
U6 & 1. stupeň ZŠ & speciální pedagogika \\
U7 & tělesná výchova & \\
U8 & německý jazyk & základy společenských věd \\
U9 & občanská výchova & dějepis \\
U10 & speciální pedagogika & výchova ke zdraví pro ZŠ \\
U11 & německý jazyk & ruský jazyk \\
U12 & 1. stupeň ZŠ & \\
U13 & matematika & tělesná výchova \\
U14 & biologie & zeměpis \\
U15 & biologie & základy společenských věd \\
U16 & 1. stupeň ZŠ & \\
U17 & matematika & fyzika anglický jazyk \\
U18 & český jazyk & dějepis \\
U19 & 1. stupeň ZŠ & \\
U20 & 1. stupeň ZŠ & \\
\hline
\end{tabular}

\subsection{Metody sběru a analýzy dat}

Sekundární analýza dat získaných v rámci rozhovorů byla koncipována jako doplňující analýza (supplementary; např. Heaton, 2008), pro kterou je typické stanovení nových výzkumných otázek pro analýzu dřive získaných dat. Jako výhodu a eliminaci potenciálních rizik spatřujeme skutečnost, že jsme sami sbírali data pro primární analýzu, nešlo o data převzatá, jsme obeznámeni s kontextem primárního výzkumu, přistupujeme tudíž $\mathrm{k}$ datům $\mathrm{s}$ jejich plným pochopením (více k problematice výhod a rizik sekundární analýzy viz Johnston, 2014).

Polostrukturovaný rozhovor realizovaný $v$ původní studii byl členěn do tří navazujících sekcí - úvodní část se zahajovacími otázkami, otázky pro podskupiny podle profesních záměrů (zůstat ve škole, či odejít), které sledovaly především okolnosti jejich rozhodování a průběh jejich profesního působení, a otázky shrnující, zaměřené na celkové hodnocení jejich spokojenosti v oblastech, které reprezentují hlavní domény dotazníku. Byla zařazena i otázka na další významné okolnosti, jež nebyly $v$ dosavadním dotazování tematizovány. 
Do struktury rozhovoru nebyly zařazeny otázky směřující přímo k profesnímu aktérství, což pro navazující analýzu považujeme spiše za výhodu, protože výpovědi učitelů o jejich profesním aktérství lze považovat za spontánní, nikoli vyžádané. Právě takové odpovědi jsme při prvotní analýze považovali za významnější. Celý scénář rozhovoru lze dohledat v monografii Hanušová et al. (2017).

Audiozáznamy rozhovorů byly transkribovány, transkripty byly uloženy v prostředí MaxQDA a dále byly podrobeny obsahové analýze. Analytickou jednotku pro kódování představoval myšlenkový celek (idea unit). Analýza byla kombinací induktivních a deduktivních postupů, přičemž v prípadě profesního aktérství šlo nejprve o indukci $\checkmark$ průběhu primární analýzy, kdy se projevy profesního aktérství jevily natolik významné, že jsme se je rozhodli dále zkoumat v rámci sekundární analýzy. Sekundární analýza proběhla ve dvou krocích. Prvním krokem byla identifikace myšlenkových celků (výroků), jež svědčily o profesním aktérství (jednotlivé myšlenkové celky mohly spadat do více než jedné kategorie, nebyly tedy disjunktní), dále následovalo přiřazování myšlenkových jednotek do kategorií deduktivně stanovených na základě teorie (Goller, 2017, viz podkapitola 2.2): (a) aktérské dispozice, (b) aktérské jednání, (c) výsledky aktérského jednání, (d) vliv prostředí na uplatňování aktérských dispozic, resp. na aktérské jednání. $V$ této fázi byl každý transkript kódován dvěma kódovatelkami, které své výsledky společně konzultovaly a dolad'ovaly př́padné nejasnosti.

\section{Výzkumná zjištění}

Než přistoupíme k prezentaci výsledků, které budeme strukturovat jako odpovědi na výzkumné otázky, je třeba zdưraznit, že jsme sledovali subjektivní vnímání profesního aktérství začínajících učitelů v souvislosti s jejich profesní socializací. Neaspirovali jsme na zachycení objektivního stavu věcí a navíc se relevance aktérství vynorila v rámci zkoumání objektivních determinant socializace, nebyla tedy primárním cílem původního výzkumu. Jednotlivé kategorie jsou velmi úzce provázány a jsou vzájemně podmíněny: nelze si např́klad představit aktérské jednání bez aktérských dispozic. $Z$ důvodu omezeného rozsahu tohoto textu a s ohledem na zaměření tohoto monotematického čísla časopisu budeme odpovědi na první tři otázky prezentovat stručněji, abychom se mohli důkladněji věnovat poslední otázce, která se nejvíce vztahuje ke spolupráci v rámci učitelského sboru.

\subsection{Projevovaly se ve výpovědích začínajících učitelů aktérské dispozice?}

Kategorii aktérských dispozic jsme zachytili v analýze transkriptů celkem 46krát. Objevila se ve výpovědích 15 učitelek $z 20$, u každé $z$ nich v průměru třikrát.

Ačkoli jsme se zaměřovali na začínající učitele, i jejich krátká zkušenost se z hlediska aktérských dispozic jevila jako formující. Goller (2017) v této souvislosti hovoří 
o tzv. aktérské kompetenci (agentic competence), která je nezbytnou komponentou aktérství - učitel musí být schopen podložit své rozhodování a jednání adekvátním profesním věděním. Učitelka U20 hovoří dokonce o „prozřeni““:

Hodně se změnilo to, že ted' už vím spoustu věcí, o kterých jsem předtím neměla vưbec tušení, co se týká třeba administrativních věcí, co vlastně ten učitel musí všechno udělat... Změnilo se toho hodně. Víceméně téměř všechno, protože já jsem šla jenom z takových pár znalostí do toho, jak to funguje ve skutečnosti, takže, takovéto prozření je to, nebo já nevím. (U20)

Učitelky $v$ rozhovorech vyjadřovaly názory na jednotlivé aspekty učitelské práce, včetně názorů na učitelství jako profesi a její prestiž, české školství a změny, které $v$ něm probíhají v poslední době (např. inkluze), nebo na prostředí konkrétní školy ( $k$ tomu podrobněji v odpovědi na V04). Názory byly často kritické a obsahovaly kromě hodnoticích soudů také návrhy na možné změny (právě toto Eteläpelto, Vähäsantanen, \& Hökkä, 2015, považují za typický projev aktérství). Následující úryvek ilustruje pohled na kariérní ŕád, jehož zavedení bylo $v$ době realizace rozhovorů aktuální:

Možná bych uvažovala o tom kariérním řádu, jestli je to dobré, nebo jestli by to nešlo nějak upravit. Jestli je to vhodné, jestli by nebylo lepší zůstat u tradičního přistupu než rozdělovat učitele do nějakých tří stupňủ... ten začátečník kolikrát může být lepší než nějaký učitel, který učí třicet let a učí třicet let stejným zpưsobem... Takže nad tím hodnocením a vzděláváním učitelů bych se pozastavila, ale zase ne, že bych to úplně zatracovala. (U9)

Vedle aktérské kompetence je podle Gollera (2017) další nezbytnou složkou aktérství tzv. aktérské přesvědčení (agency beliefs), jiní autoři v tomto smyslu mluví o „smyslu pro aktérstvi““ (sense of agency; srov. Vähäsantanen et al., 2017, a koncept identity agency; rovněž Beauchamp \& Thomas, 2011; Biesta et al., 2015). Profesní filozofie, kterou některé učitelky $v$ našem souboru byly schopny poměrně pregnantně formulovat, často zahrnovala velmi explicitní vyjádření o nutnosti aktérství, které je předpokladem $\mathrm{k}$ tomu, aby si učitel uspořádal svou práci a přizpůsobil pracovní prostředí tak, aby mohl působit v souladu se svým přesvědčením. Eteläpeltová et al. (2015) v této souvislosti hovoří o potřebě revidovat profesní ideály, které si učitel utvářel během svého přípravného vzdělávání, a budovat profesní identitu, jež je postavena také na realistickém pohledu na vlastní zájmy a reálné kompetence.

No, asi nejvíc jakoby kvůli mně samotné, ve smyslu, že já jsem si musela utřídit, co vlastně, jakoby, filozoficky jsem si to musela nějak jako usadit. $K$ čemu já tam jsem. $K$ čemu vůbec prostě tohle má směřovat, co je vlastně mým cílem, protože... jakou metodu já zvolím, nebo mám zvolit, proto, abych toho cíle dosáhla, protože fakt to bylo hodně takový pro mě psychicky, filozoficky, jestli mi rozumíte, jako náročný. (U16) 
$\checkmark$ několika př́padech jsme zaznamenali při této nové formulaci profesních ideálů kolizi s reálnou situací ve školách, kde, slovy jedné z respondentek: ,,... ta realita se nepotkává s tou mojí představou, jak by to mělo jako být... myslela jsem si, že třeba některé věci jde snadněji změnit nebo prosadit..." (U6). Za aktérskou dispozici jsme $\checkmark$ podobných případech považovali nejen snahu hledat nová řešení, najít spojence ve škole, ale i pokus o smíření se se stavem věcí, který nelze změnit (,... je to prostě prưřez společností, tak se s tím musí člověk nějak smiŕit" - U17; výrok se vztahuje $k$ žákovské populaci). Je však zřejmé, že tyto př́pady naplňují vymezení pojmu omezené aktérství (bounded agency; Evans, 2002). Idealizovaný pohled měly některé učitelky $v$ našem souboru i samy na sebe, své schopnosti a možnosti. Některé z nich se vyjádřily v tom smyslu, že se jim podařilo svůj perfekcionismus si již v začátcích své profesní dráhy uvědomit a relativizovat (srov. Billett, 2011 - personal agency; rovněž Goller, 2017, pracuje s touto komponentou aktérství):

Brala jsem to určitě víc vážně, než to ve skutečnosti je... Pro mě jakoby samotná ta vyučovací hodina byla něco, co musí proběhnout přesně takhle, takhle a takhle, což jsem zjistila, že se stát nemusí, že když se to prostě jednou třeba nepovede, nebo to nevyjde úplně tak, jak by mělo, takže se vlastně nic neděje, to mě trošku uklidnilo. (U5)

Častěji než toto jakési realistické „smiřeni““ se ale objevovala vyjádření svědčící o tendenci k proaktivnímu př́stupu, který učitelky formulovaly v několika případech jako odpověd’ na otázku, co by vzkázaly učitelům na samém počátku kariéry. Následující ilustrativní výroky svědčí o vědomém aktérském př́istupu respondentek k profesní iniciaci i o přesvědčení o nezbytnosti aktérství (srov. Eteläpelto et al., 2013; aj.): „Ale prostě nechat to tak nějak i na své intuici všechno. Nenechat si nic nakukat.“ (U12) „No, já moc nemám ráda takový ten laxní přistup. Jakože nic se nedělá, protože nic nemá cenu. “(U7)

$\checkmark$ některých př́padech se aktérské dispozice učitelek v našem souboru projevovaly jako zvažování, zda odejít na jinou školu (o odchodu ze školství se v tomto smyslu nevyjádřila žádná z nich). Změna školy byla popisována jako snaha najít školu, kde bude možné realizovat lépe vlastní představy o podobě výuky - respondentka zde zcela konkrétně formuluje cíle aktérství v podobě konkrétní změny (transformační aktérství, viz Vähäsantanen et al., 2017) a realisticky zvažuje vlastní aktérské jednání v situaci, kdy jsou jeho cíle v nesouladu s vizí školy:

Já bych chtěla zkusit nějaký jiný typ školy. Zkusit nějakou Montessori školu nebo něco... Asi bych si musela vymyslet třeba svůj vlastní způsob, jak bych si to přála... že by o přestávce děti mohly jít do tělocvičny si hrát, že bych si mohla přehazovat hodiny, jak bych chtěla, že by mohly mít tolik a tolik minut, že bych ten tematický plán si přizpưsobila, prostě, že bych si to přizpůsobila tak, jak já to považuji za nejlepší... a že bych mohla jako kdyby pracovat tady tímhle tempem, kterým bych potřebovala. (U1)

Za aktérskou dispozici považujeme v souladu s Eteläpeltovou et al. (2013) a dalšími také úsilí o vlastní profesní rozvoj a další vzdělávání, které bylo tematizováno $\checkmark$ šesti rozhovorech. Typickým vyjádřením je výrok učitelky U19: 
Na co se těším při vývoji vlastní dráhy? No tak já se celkem dost často těšívám, když mám nějakou možnost vzdělávání jakéhokoliv druhu, co mi pomůže při mé profesi zlepšovat výuku, metody výuky. Takže na možnost vzdělávat se a poznávat nové věci. (U19)

Možnost projevit ve škole své aktérské dispozice se ukázala jako velmi významná i pro setrvání učitele ve škole:

A čím mám jakoby větší slovo, tak tím míň se mi chce odtamtud odejít. (U10)

\subsection{Jak vypovídali začínající učitelé o vlastním aktérském jednání?}

Výpovědi o vlastním aktérském jednání byly nejčastěji zastoupenou kategorií. Identifikovali jsme je u všech 20 učitelek v celkovém počtu 85 výpovědí (tedy průměrně čtyři výpovědi na jednu učitelku, přičemž maximální počet byl 12 výpovědí učitelky U10). Tyto rozdíly mohou být v souladu s Gollerovým (2017) rozlišením „aktérských“ a „ne-aktérských“ jedinců.

Aktérské jednání, byt’ orientované na vlastní profesní cíle (srov. Vähäsantanen et al., 2017 - individuální aktérství) se v několika případech týkalo už hledání zaměstnání ve škole, $v$ jednom případě respondentka popisovala cílevědomé kroky směřující k cestě do školství a poté do konkrétní školy již od svého dětství:

Už asi od páté třídy jsem chtěla být paní učitelka a tak nějak jako postupně jsem si $\mathrm{k}$ tomu přicházela přes rưzné překážky, těžkosti a nakonec, přestože jsem chtěla být původně na prvním stupni, došla jsem tam, kde jsem, a jsem za to ráda. (U3)

Za aktérské jednání je ale třeba považovat i odchod ze školy (srov. Priestley et al., 2015; aj.), pokud učitel zváží nekompatibilitu vlastního pojetí učitelství s působením v konkrétní škole, s nímž jsme se setkali u tří učitelek a o němž se ještě zmíníme v pasáži věnované výsledkům aktérského jednání.

$\checkmark$ této analýze zaměřujeme pozornost především na profesní aktérství noviců ve škole jako organizaci, tj. ve vztahu ke kolegům, vedení školy, sdíleným normám a praktikám. Řada výpovědí o aktérském jednání je ale samozřejmě zacílena na širší aspekty základní funkce školy, na práci s žáky. Aktérské jednání je v tomto směru bohatě rozvíjeno: výpovědi respondentů tematizují kreativitu, hledání nových cest, budování vlastní autority, činnost nad rámec základních povinností (např. zapojení do projektů, tvorba webových stránek školy, pořádání mimoškolních aktivit pro žáky) a kreativní prrístup k řešení problémů. Společným jmenovatelem je zde proaktivita a usilování o změnu, což se překrývá s pojetím aktérství podle Eteläpeltové et al. (2013). Zcela zásadní byla podle jedné respondentky možnost

... někoho jakoby ovlivnit, nebo i řídit někoho, i se jako trochu realizovat, $v$ tom, že si můžu prostě to učení přizpưsobit úplně, jak chci já, a... i tam mám třeba nějakou tu... nevím třeba administrativu, a to mě baví... (U10) 
Následující výrok ukazuje připravenost k aktérskému jednání v náročné situaci:

Už se těším na to, až moje třída přejde do sedmé třídy, protože tam je ta nejtvrdší puberta, tak už si připravujeme projekty a takové ty věci, jako co se s nimi bude dělat, jakým způsobem se budou rozvíjet. Opravdu ta třída mě baví, jako věnuji se jí a tak. (U17)

Gaikhorstová a její kolegové v této souvislosti upozorňují, že problémy identifikované začínajícími učiteli v oblasti práce s náročnými žákovskými skupinami bývají vnímány spíše jako zajímavé výzvy (z našeho hlediska výzvy podporující aktérské jednání) než jako překážky (Gaikhorst et al., 2017).

Aktérské jednání jsme vnímali také v případech, kdy učitelky přistupovaly proaktivním způsobem ke spolupráci s kolegy, případně mentory (,at' se nebojí zeptat, at' se nebojí ukázat, že něco neví třeba, a říct, nechat si poradit“ - U6; srov. Vähäsantanen et al., 2017, a koncept dialogického aktérství). Podrobněji se o této spolupráci zmíníme v pasáži o vlivu prostředí na aktérství.

Některé učitelky v našem souboru si uvědomovaly určité meze aktérského jednání, které by nemělo vycházet $z$ přehnaných nároků na sebe a nemělo by vést $\mathrm{k}$ přetížení učitele se všemi jeho důsledky. V následujícím výroku lze zároveň identifikovat konfliktní rovinu míry individuálního a kolektivního aktérství, která vede k určité aktérské rezistenci jedince (Evans, 2002):

A co se týče toho vyučovacího procesu a těch žáků, tak aby... nebyl přehnaně aktivní, protože... za prvé to nikdo nijak extra neohodnotí, co mám zkušenost já, a prostě, dělat to tak, aby člověk byl spokojený. Prostě udělat to tak, abych mohla spokojeně odcházet domů, že jsem udělala všechno, jak jsem měla. (U10)

\subsection{Jak vypovídali začínající učitelé o výsledcích svého aktérského jednání?}

Výpovědí o výsledcích aktérského jednání bylo přirozeně nejméně, objevily se pouze u 11 učitelek a celkově jsme jich identifikovali 17, tedy v průměru 1,5 výpovědi na respondentku.

Výsledky aktérského jednání je možné spatřovat jako pozitivní vyústění takového jednání, např. získání trvalé pracovní smlouvy:

Já jsem dostala vlastně původně smlouvu na rok, jenomže jsem se tak nějak začala angažovat i ve věcech mimo tu výuku, třeba webový stránky dělám a tak nějak různě, ted'ka se zapojuju do projektů a tak, takže mně pan ředitel nabídl smlouvu na dobu neurčitou. (U5)

- nebo spokojenost s pưsobením ve škole, spojená s vnímáním smysluplnosti a možnosti ovlivnit působení školy jako celku:

Jakože tady je dost velká jakoby svoboda v tom, co člověk vlastně chce dělat, jak to chce dělat, jak to chce realizovat... že víme, kam směřujeme tak nějak, kým že je ta 
škola... když jsem si usmyslela, že bych chtěla s nimi dělat jiné programy, než se dělaly tam, vlastně už promyšlené, tak samozřejmě nebyl problém předělat, předělali jsme si v podstatě systém a mohla jsem si dělat podle svého... (U17)

Tyto výpovědi naplňují definici transformačního aktérství noviců (Vähäsantanen et al., 2017) jako dosažení žádoucích cílů, tj. individuální a kolektivní aktérství jsou ve shodě a výsledky lze považovat za pozitivní.

Setkali jsme se ale i s výroky o nepřiznivých výsledcích aktérského jednání. Naše respondentky referovaly např́iklad o konfliktu s kolegy následujícím po aktérském jednání ve prospěch žáků, o vnímání aktérského jednání jako komplikace běžného provozu školy ze strany vedení, případně o „vystřílivěni““, které bylo popsáno následovně:

Já jsem si myslela, že když si člověk bude dělat všechno tak, jak si myslí, že je to správně, jako... je přesvědčený o tom, že to je takhle správně a že by to takhle měl dělat každý, a zjistí, že to tak prostě není, že každý má prostě jiný názor na tu věc, tak takové to vystřizlivění, prostě, jak říká kolegyně: „dělám do výše svého platu“... člověk už není úplně aktivní a nesnaží se dělat všechno možné, protože pak zjistí, že se nikomu nezavděčí a že ti lidi, že i ti rodiče prostě... že vlastně není nikdo, kdo se na člověka nepodívá jinak, když si udělá o pět hodin víc nebo o pět hodin míň. (U10)

Výsledkem aktérského jednání sui generis může být i odchod učitele do jiné školy, případně ze školství. Nelze jednoznačně říci, že odchod ze školy je negativním důsledkem aktérského jednání, ačkoli z hlediska fungování školy jsou odchody kvalifikovaných učitelů nežádoucí. Yinonová a Orland-Baraková (2017) prosazují salutogenní pohled na odchody učitelů a spatřují v nich projev aktérství a aktivního př́stupu $\mathrm{k}$ budování vlastní kariéry. Tři respondentky $\mathrm{v}$ našem souboru změnily již v prvních letech v profesi školu a všechny byly s touto změnou spokojeny. Následující výrok je typickým vyjádřením jedné z nich:

Už vím, že se to dá dělat jinak. Na předešlé škole mi všichni ř́kali: „Všude je to stejné.“ Ale já jsem odešla, protože tomu nevěřím a chtěla jsem někam jinam. A ted' už vím, že to jinak jde dělat. (U11)

\subsection{Jak vnímali začínající učitelé vliv prostředí (školy jako organizace) na své aktérství?}

Odpověd' na tuto otázku je pro náš výzkum klíčová. O vlivu faktorů spojených s prostředím školy hovořily všechny učitelky $v$ našem souboru kromě jedné. Celkový počet 69 výroků (tedy druhá nejvíce zastoupená kategorie) znamená průměrně 3,6 výroku na jednu učitelku (maximální počet 11 výroků se vyskytl u učitelky U10).

$\checkmark$ rámci vlivu prostředí školy se budeme věnovat nejprve působení vedení školy, poté kolegů včetně spolupráce $s$ mentory a nakonec se dotkneme oblasti materiálních a platových podmínek ve škole a pracovního zatížení. Větší část výpovědí svědčila o pozitivním vlivu prostředí školy na aktérství učitelů, objevily se však i některé 
100 výroky o jednoznačně negativním působení. Ty byly časté zejména v případech, kdy učitelky změnily školu, popř́padě pokud se vyměnilo během jejich působení ve škole vedení a ony tak získaly možnost srovnávat.

\section{Vliv vedení školy}

Pozitivní hodnocení ředitelů a dalších členů vedení školy se objevovalo tam, kde začínající učitelé cítili podporu (často ve srovnání s bývalým vedením nebo vedením na jiné škole). Preferováno bylo vedení, které je otevřené novým přistupưm, dává začínajícím učitelům zodpovědnost a nechává je projevit aktérský př́stup:

Pan ředitel nás nechá pracovat samotné a chce ten výsledek... Nechají nás dělat projekty. Tam jsem měla problém dělat projekt, jaképak přehazování předmětů... A ted'ka máme volnou ruku a není s tím žádný problém. (U2)

Inspirující bylo vedení školy zejména v případě, kdy projevovalo aktérské jednání a tím povzbuzovalo i aktérské jednání učitelů (inspirational leadership style; Secretan, 1999):

Já si myslím, že my máme tak skvělou a schopnou zástupkyni. Naše škola jde podle mě jen nahoru... a ona to vede tak, že využíváme všechny projekty... můžeme mít nové učebny, kdykoliv cokoli je, tak ona nás do všeho ne že nutí, ale je hodně aktivní, takže ví, kde si můžeme přivydělat, ví, kde můžeme získat nějakou učebnu a do toho všeho jde, takže to se mi hrozně na té škole líbí. (U18)

Velmi vysoce učitelky oceňovaly podporu vedení, které stojí za učiteli v konfliktních situacích, pomáhá jim řešit problémy („,Vedení se mě zastalo, všichni vlastně jako úplně do jednoho, a tak to jsem věděla, že když se za mě jako postaví, tak že mě tam prostě chtějí a že bych tam měla být..." - U10) a, obrazně řečeno, má pro učitele vždy otevřené dveře:

Tak pro mě třeba bylo důležité, že vím, že kdykoliv bude nějaký problém nebo budu něco řešit, že se nemusím bát, že za ním mưžu přijít, za tím ředitelem, a mǔžu to řešit $\mathrm{s}$ ním, že v něm ten učitel jakoby měl tu oporu, podporu. (U8)

Oceňováno bylo i vedení, které podporuje profesní rozvoj učitelů včetně takových forem, jako jsou vzájemné hospitace ve výuce (,,... nám řekli, že kdybychom my měli jako zájem, že se můžeme podívat na kolegy, abychom viděli, jak se třeba uči“ - U10).

Ne zcela pozitivně byli vnímáni ředitelé, kteří nedokázali dostatečně autoritativně vést učitele (,... pan ředitel je na nás hrozně hodný, což ale není podle mě někdy role ředitele. On by si měl někdy dupnout a ríci: ,Takhle to bude a hotovo.‘ Místo toho řekne: ,Udělejte si to tak, aby vám to vyhovovalo. ““ - U5) nebo pokud pouze „trpěli“ aktérské jednání učitelů a v podstatě dávali najevo, že je komplikací běžného provozu školy: 
Na vysoké nám říkali, že je fajn jakákoliv vedlejší aktivita, kterou se žáky děláme, cokoliv mimo výuku, abychom je přitáhli k tomu oboru nebo ke škole jako takové, různé kroužky, semináře, projekty a podobně. A mně se zdá, že na to ve škole není moc ne místo, ale spíše vstřícnost ze strany vedení. Když se rozhodnu, když někam chci s dětmi jet a podobně, tak se řeší, kdo bude suplovat a kdo bude zaskakovat a jak organizačně a nevím co ještě. Většinou je to takové: „No dobře no, ale výjimečně.“ (U14)

Jako vysloveně negativní vnímaly učitelky situace, kdy se vedení školy nezastalo učitele $(, \ldots .$. on se kamarádil s rodiči těch žáků, ale to byla taková, jakože lepší čtvrt' ve městě... Ale vedlo to $k$ tomu, že si mohli dovolit všechno a my jsme $v$ tom vedení neměli zastání, což mně začalo hrozně vadit...“ - U12). V konkrétním případě učitelky U12 situace ve škole nakonec vedla $k$ jejímu odchodu. Ze školy odešla i učitelka U11, která popisuje styl vedení v anglosaské odborné literatuře (Bush, 2003; aj.) trefně nazývaný garbage can leadership, kdy se problémy neřeší, ale „házejí se do odpadkového koše“. Jakýkoli projev aktérství narušuje zaběhlý pořádek, je tedy nežádoucí:

Tam byla ta hranice taková nízká, nikoho vlastně nezajímalo, co děláte. Nebylo tam nic motivujícího ze strany vedení, abych tam zůstala, prostě nějaký ten pocit toho sebeuplatnění. Prostě mouchy, snězte si mě. Nevím, jak lépe to mám říci. Kdyby vedení z jejich strany bylo víc takové motivující, hodnotící. Kdyby viděli tu snahu, kdyby dokázali dát zpětnou vazbu. (U11)

Bránění aktérskému jednání ze strany vedení školy se v několika př́padech projevilo v oblasti dalšího vzdělávání učitelů. Učitelka U3 popisuje, jak jí ředitelka školy nepovolila dostudovat speciální pedagogiku, přestože by to bylo $v$ době inkluze pro školu př́nosné. Dále potom hovoří o zamítnutí možnosti navštívit zvolené školení, což následně vedlo $\mathrm{k}$ jejím úvahám o změně školy:

Třeba jsme měly s asistentkou vybrané školení o spolupráci učitele a asistenta, ale protože $v$ tom nás inspekce pochválila, tak to nám bylo zamítnuto, že $v$ tom už se rozvíjet nebudeme. (U3)

\section{Vliv kolegů (včetně mentoringu)}

Po vlivu vedení školy na aktérství učitele jsme se soustředili na spolupráci učitelů $\mathrm{s}$ kolegy $\mathrm{v}$ učitelském sboru. Většina výroků týkajících se kolegů byla pozitivní (25 výroků). Zaznamenali jsme např́klad popis tzv. integrované kultury školy (Kardos et al., 2001), která je charakterizována spoluprací všech generací učitelů, je příznivá z hlediska rozvoje aktérství začínajících učitelů a podporuje relační aktérství (Edwards, 2005).

Ti učitelé, kteři mají prostě před důchodem třeba a mají spoustu let praxe, tak se mně nikdy nestalo, že by na mě koukali jako na něco mín jenom proto, že tu zkušenost nemám. Naopak se mě snažili jakoby podporovat $v$ tom, že to zvládnu stejně dobře jako oni. A to je asi součást toho vedení, ani vedení mně nikdy jako nenaznačilo, že: „Ty seš tady prosím tě týden, tak jako nemachruj. “ (U5) 
Z hlediska relačního aktérství je velmi důležitá spolupráce a sdílení materiálů: „,... nebo někde najdu něco kvalitně zpracovaného. Tak si poskytujeme vzájemně s těmi vyučujícími...“ (U13) - a rozvoj pozitivního klimatu školy:

Ráno jdu do práce a těším se. Vím, že když přijdu do práce, do sborovny, tak že tam bude pozitivní nálada. Nikdo tam nebude koukat, nebude smutný... Když pak jdeme do té výuky, jdeme společně s těmi kolegy, podporujeme se, pomáháme si. (U9)

V rámci kolegiální spolupráce $v$ učitelském sboru byl jako velmi významný zmiňován vlastní proaktivní př́stup. Začínající učitel „se má snažit hned od začátku se s těmi kolegy hlavně prostě jakoby líp poznat... aby prostě zapadl do toho kolektivu“ (U10), „začínající učitel by se neměl bát na cokoliv zeptat“ (U9). Podobně učitelka U13 vnímá jako důležité, ,jestli se člověk sám ptá a pídí po něčem takovém. Jako jsou lidi, kteří se tam neptají nebo nebaví. Ale já se snažím bavit se s většinou lidí, nebo s těmi, co potřebuju spolupracovat...“.

Mezi negativními vlivy se ve třech případech objevily výroky svědčící o existenci tzv. veteránské kultury školy (Kardos et al., 2001), která se vyznačuje rigiditou a nedostatkem podpory začínajících učitelů, přičemž nedává těmto učitelům ani dostatek prostoru pro jejich aktérství:

Ta organizace je, že si hodně jedeme v těch zajetých kolejích, co máme už třicet let, a jenom, aby se něco změnilo, tak to trvá půl roku... protože ta naše škola měla loni třicet let a jsou tady někteří pedagogové, kteří jsou tady od úplného začátku a jedou si pořád to svoje. (U5)

Pokud jde o mentoring, ne všechny učitelky měly přiděleného mentora a ne všichni mentoři byli vnímáni jako aktivně podporující. Tři učitelky hodnotily spolupráci s mentorem jako velmi dobře fungující, přičemž jedna zdůrazňovala aktérské jednání začínajícího učitele $v$ rámci této spolupráce. Nabízí se srovnání s výzkumem Caspersena a Raaena (2014), kteří zjistili, že začínající učitelé někdy nabízenou podporu nevnímají či ji nejsou schopni vyžádat a posléze přijmout.

\section{Vliv materiálních a platových podmínek ve škole a pracovního zatižení}

Kromě vlivu vedení školy a kolegů bylo aktérství učitelů v některých případech ztiženo také nedostatečnými materiálními podmínkami ve škole („Kopírovat jsme nesměli ve škole. Neměli jsme kopírku, takže já jsem si brala peníze od rodičů, abych to mohla tisknout doma...“ - U2) a pracovním přetižením:

Protože když jsem se na všechno chtěla připravovat prostě tak, abych cítila, že jsem se na to připravila dobře, na ty hodiny, tak jsem, ani nepřeháním, strávila včetně práce tak od odchodu do práce do toho, než jsem skončila prípravu do práce, tak bylo fakt jako dvanáct, čtrnáct hodin denně. (U16)

Podobným faktorem bylo také př́lišné časové zatížení v kombinaci s nedostatečným platovým ohodnocením: 
Tak aby se do toho hned zapojil, hned to rozjel, tak musí si to připravovat, musí si udělat plán, musí třeba získat od kolegů nějaké rady, ale aby se mu chtělo, musí za to být dostatečně ohodnocený a musí pak mít i čas na to, aby nějak odpočival a tak. (U1)

\section{Diskuse a závěr}

Profesní aktérství se jako jedna z determinant rozhodování o vlastní profesní budoucnosti vynořilo ve výzkumu profesní socializace začínajících učitelů. Možnost aktivně rídit vlastní profesní vývoj a ovlivňovat dění ve škole měla vliv na rozhodování noviců, zda ve škole setrvat, či odejít na jinou školu, případně i ze školství. K zaměření na profesní aktérství nás motivovaly nejen výsledky výzkumu drop-outu začínajících učitelů v základních školách, ale i dřivější výzkum expertnosti učitelů anglického jazyka (Píšová et al., 2013). Jeho výsledky naznačily, že jedním z charakteristických rysů učitelů expertů bylo právě silné profesní aktérství, a to nejen na úrovni smyslu pro aktérství, tj. „prožitku ovládání jak vlastních akcí, tak skrze ně i událostí ve vnějším světě“ (Haggard \& Tsakiris, 2009, s. 243), ale také na úrovni aktérského jednání. Silné profesní aktérství je předpokladem dosažení a udržování tzv. adaptivní expertnosti (adaptive expertise; Hatano \& Inagaki, 1986; podrobněji k tomuto konceptu Píšová et al., 2013, s. 14, 18, 192); v podmínkách permanentní změny se právě adaptivní expertnost jeví pomyslným horizontem kvality, k němuž by učitelé (ale i studenti učitelství) měli směřovat (Darling-Hammond \& Bransford, 2005).

V našem výzkumu jsme vycházeli ze subjektově orientovaného pojetí profesního aktérství, konkrétní teoretickou oporu představoval Gollerův (2017) koncepční rámec profesního aktérství učitelů. Formulace cílů výzkumu i jim odpovídající výzkumný design svědči o tom, že se nám jednalo o profesní aktérství začínajících učitelů konceptualizované jako individuální fenomén, který je kontextově situován a kontextem (sociokulturním i materiálním) ovlivňován. Nezabývali jsme se tedy účinky profesního aktérství začínajících učitelů na fungování organizace (školy včetně žáků a jejich učení), ale naopak: usilovali jsme o zjištění, jak vliv organizace na vlastní profesní aktérství vnímají začínající učitelé.

Prvním nezbytným krokem tudíž bylo zjistit, zda a jak začínající učitelé vypovídají o vlastních aktérských dispozicích i aktérském jednání včetně jeho výsledků. Výstupy analýzy výpovědí začínajících učitelů umožňují konstatovat, že už u začínajících učitelů lze hovořit o značné míře profesního aktérství. Jak identifikované projevy aktérských dispozic, tak profesního jednání přitom svědčí jednak o tendencích dosáhnout změny u sebe samého, tj. obzvláště si stanovovat cíle vlastního profesního učení a rozvoje a formovat svou profesní dráhu, ale rovněž o tendencích dosáhnout změny současných pracovních vzorců a praktik či sociálních vztahů v rámci školy. Jinými slovy, jednalo se o projevy individuálně i externě orientovaného aktérství (Harteis \& Goller, 2014, s. 44).

Vliv faktorů na úrovni školy, konkrétně kolegů, vedení školy a klimatu školy, na aktérské dispozice i jednání začínajících učitelů se v našem výzkumu ukazuje jako 
zcela zásadní. Možnost uplatňovat vlastní aktérské dispozice $v$ jednání na interaktivní (školní třída) i institucionální (zde zejména spolupráce $v$ učitelském sboru) rovině socializace (Pollard, 1982; podrobněji in Hanušová et al., 2017) v aktérském jednání je podmínkou profesního učení a profesního rozvoje začínajících učitelů, přispívá k profesní spokojenosti učitelů a zvyšuje šance na jejich setrvání na škole. Zároveň tak individuální aktérství noviců může přispívat do „fondu“ distribuované expertnosti v rámci učitelského sboru jako učící se profesní komunity. Z hlediska podpory aktérského jednání jednotlivých učitelů i celého učitelského sboru jsme identifikovali klíčovou roli vedení školy, zejména jeho otevřenosti a podpory inovací (transformational leadership). Naše výzkumná zjištění tudíž naznačují, že zkoumání profesního aktérství v rámci učitelských sborů v českých školách může být velmi prínosné, a to nejen u začínajících učitelů.

Uvedená zjištění do značné míry korespondují s výsledky výzkumu Eteläpeltové et al. (2015) zaměřeného na aktérství začínajících učitelů ve finských školách. Je zajímavé, že i v podmínkách vysoce oceňovaného finského vzdělávacího systému, $\checkmark$ němž existují jen minimální omezení učitelské autonomie (Hökkä \& Eteläpelto, 2014), se začínající učitelé potýkají s pocity omezeného aktérství a silně vnímají tenze spojené se vstupem do nového profesního prostředí. I v tomto výzkumu reprezentoval ředitel, resp. vedení školy, hlavní omezení a zároveň hlavní zdroj podpory aktérství noviců $v$ profesi. To je jeden z nálezů, které ukazují na důležitost požadavku expertní vícezdrojové podpory aktérství začínajících učitelů jako podmínky jejich úspěšné profesní adaptace a dalšího rozvoje.

Jako každý výzkum, i zde prezentovaná sonda má své limity. $\mathrm{K}$ nim mj. patří pouze $15 \%$ úspěšnost při oslovování potenciálních respondentů pro rozhovory. Respondentkami kvalitativní fáze výzkumu se tím pádem staly téměř výhradně nadšené učitelky, které vykonávají svou práci s velkým nasazením a které neodmítly možnost uvažovat o své práci v rámci rozhovorů s námi. Jednalo se tedy zřejmě o učitelky vykazující vyšší míru profesního aktérství, než je v populaci běžné. Neaspirujeme tedy na zobecnění výsledných zjištění, ale spíše doporučujeme další výzkum v oblasti profesního aktérství (nejen) začínajících učitelů.

Jako další limit by se mohlo jevit zkoumání „pouhých“ subjektivních percepcí učitelů. Jsou to ale právě tyto subjektivní percepce, které vedou učitele k rozhodování o dalším setrvání ve škole či v profesi a o míře projevení jejich aktérského jednání $\checkmark$ rámci učitelského sboru.

Pojem aktérství pro pedagogický výzkum reprezentuje relativně novou optiku, již Ize nahližet na učitele a jeho profesní život, ale i na školu a její rozvoj. V souladu s Gollerovým (2017) pojetím vnímáme aktérské dispozice jako osobnostní rys, který se projevil u učitelek v našem souboru většinou již před nástupem do profese. Proto považujeme za podstatné rozpoznání, uznání a rozvíjení těchto dispozic již během př́pravného vzdělávání učitelů.

Pro optimální fungování mechanismů podporujících socializaci začínajících učitelů je podmínkou, bez níž se jen těžko lze obejít, spolupráce mezi vzdělavateli učitelů a školami. Pro další směřování k novým variantám podpory profesních začátků 
učitelů v ČR bude proto velmi důležité zvážit jak koncepci adaptačního období včetně spolupráce s fakultami připravujícími učitele, tak změny v př́ípravném vzdělávání učitelů (důraz na př́pravu učitelů pro období počáteční socializace, obeznámení budoucích učitelů s jejími zákonitostmi, možnými problémy a strategiemi řešení).

\section{Literatura}

Ahearn, L. M. (2001). Language and agency. Annual Review of Anthropology, 30(1), 109-137. Archer, M. (1995). Realist social theory: The morphogenetic approach. Cambridge: Cambridge University Press.

Archer, M. (2000). Being human: The problem of agency. Cambridge: Cambridge University Press.

Archer, M. (2003). Structure, agency and the internal conversation. Cambridge: Cambridge University Press.

Bandura, A. (2001). Social cognitive theory: An agentic perspective. Annual Review of Psychology, 52, 1-26.

Bandura, A. (2006). Toward a psychology of human agency. Perspectives on Psychological Science, 1(2), 164-180.

Beauchamp, C., \& Thomas, L. (2011). New teachers' identity shifts at the boundary of teacher education and initial practice. International Journal of Educational Research, 50(1), 6-13.

Biesta, G., Priestley, M., \& Robinson, S. (2015). The role of beliefs in teacher agency. Teachers and Teaching: Theory and Practice, 21(6), 624-640.

Billett, S. (2011). Subjectivity, self and personal agency in learning through and for work. In M. Malloch, L. Cairns, L. Evans, \& B. O'Connor (Eds.), The SAGE handbook of workplace learning (s. 60-72). London: SAGE Publications.

Billett, S., \& Somerville, M. (2004). Transformations at work: Identity and learning. Studies in Continuing Education, 26(2), 309-326.

Bourdieu, P. (1977). Outline of a theory of practice. Cambridge: Cambridge University Press.

Bush, T. (2003). Theories of educational leadership and management. London: SAGE Publications.

Caspersen J., \& Raaen, F. D. (2014). Novice teachers and how they cope. Teachers and Teaching: Theory and Practice, 20(2), 189-211.

Clegg, S. (2006). The problem of agency in feminism: A critical realist approach. Gender and Education, 18(3), 309-324.

Creswell, J. W., \& Plano Clark, V. L. (2011). Designing and conducting mixed methods research. London: SAGE Publications.

Darling-Hammond, L., \& Bransford, J. (Eds.). (2005). Preparing teachers for a changing world. San Francisco: Wiley.

Edwards, A. (2005). Relational agency: Learning to be a resourceful practitioner. International Journal of Educational Research, 43(3), 168-182.

Emirbayer, M., \& Mische, A. (1998). What is agency? American Journal of Sociology, 103(4), 962-1023.

Engeström, Y. (1987). Learning by expanding: An activity - theoretical approach to developmental research. Helsinki: Orienta-Konsultit.

Eteläpelto, A. (2017). Emerging conceptualisations on professional agency at work. In M. Goller \& S. Paloniemi (Eds.), Agency at work: An agentic perspective on professional learning and development (s. 183-203). Cham: Springer.

Eteläpelto, A., Vähäsantanen, K., \& Hökkä, P. (2015). How do novice teachers in Finland perceive their professional agency? Teachers and Teaching: Theory and Practice, 21(6), 660-680. 
Eteläpelto, A., Vähäsantanen, K., Hökkä, P., \& Paloniemi, S. (2013). What is agency? Conceptualizing professional agency at work. Educational Research Review, 10, 45-65.

Evans, K. (2002). Taking control of their lives? Agency in young adult transitions in England and the new Germany. Journal of Youth Studies, 5(3), 245-269.

Gaikhorst, L., Beishuizen, J., Roosenboom, B., \& Volman, M. (2017). The challenges of beginning teachers in urban primary schools. European Journal of Teacher Education, 40(1), 46-61.

Gavora, P. (2016). Preschool children in book-reading situations with parents: The perspective of personal agency theory. Studia paedagogica, 21(4), 99-115.

Giddens, A. (1984). The constitution of society. Berkeley: University of California Press.

Goller, M. (2017). Human agency at work: An active approach towards expertise development. Wiesbaden: Springer.

Goodson, I. (2003). Professional knowledge, professional lives: Studies in education and change. Maidenhead: Open University Press.

Haggard, P., \& Tsakiris M. (2009). The experience of agency feelings, judgments, and responsibility. Current Directions in Psychological Science, 18(4), 242-246.

Hájek, M. (2007). Jak nepočítat jednání: Agency in medias res, morálně uzavřený svět a teorie jednání. Teorie vědy, 16/29(2), 77-89.

Hanušová, S., Píšová, M., Kohoutek, T., Minaříková, E., Janík, M., Janík, T., ... Ježek, S. (2017). Chtějí zůstat nebo odejít? Začinající učitelé v českých základních školách. Brno: MU.

Harteis, C., \& Goller, M. (2014). New skills for new jobs: Work agency as a necessary condition for successful lifelong learning. In S. Billett, T. Halttunen, \& M. Koivisto (Eds.), Promoting, assessing, recognizing and certifying lifelong learning: International perspectives and practices (s. 37-56). Springer: Dordrecht.

Hatano, G., \& Inagaki, K. (1986). Two courses of expertise. In H. Stevenson, H. Azuma, \& K. Hakuta (Eds.), Child development and education in Japan (s. 262-272). New York: Freeman.

Heaton, J. (2008). Secondary analysis of qualitative data: An overview. Historical Social Research, 33(3), 33-45.

Hökkä, P., \& Eteläpelto, A. (2014). Seeking new perspectives on the development of teacher education - a study of the Finnish context. Journal of Teacher Education, 65(1), 39-52.

Holland, D., Lachicotte, W., Skinner, D., \& Cain, C. (1998). Identity and agency in cultural worlds. Cambridge: Harvard University Press.

Ježek, S. (2014). Aktuální pojetí autonomie v psychologii. Československá psychologie, 58(1), 31-40.

Johnston, M. P. (2014). Secondary data analysis: A method of which the time has come. Qualitative and Quantitative Methods in Libraries, 3(3), 619-626.

Kardos, S. M., Johnson, S. M., Peske, H. G., Kauffman, D., \& Liu, E. (2001). Counting on colleagues: New teachers encounter the professional cultures of their schools. Educational Administration Quarterly, 37(2), 250-290.

Lazarová, B., Pol, M., Hloušková, L., Novotný, P., \& Sedláček, M. (2012). Organizační učení v odborných diskurzech. Pedagogická orientace, 22(2), 145-161.

Leontiev, A. N. (1978). Activity, consciousness, and personality. Englewood Cliffs, NJ: Prentice Hall.

Lukášová, H. (2015). Učitelské sebepojetí a jeho zkoumání. Zlín: UTB.

Mareš, J., \& Mareš, J. (2014). Autonomie dospívajícího jedince: složitý proces, nejistý výsledek. Pedagogika, 64(1), 81-98.

Paloniemi, S., \& Goller, M. (2017). The multifaceted nature of agency and professional learning. In M. Goller \& S. Paloniemi (Eds.), Agency at work: An agentic perspective on professional learning and development (s. 465-478). Cham: Springer.

Píšová, M., \& Hanušová, S. (2016). Začínající učitelé a drop-out. Pedagogika, 66(4), 386-407.

Píšová, M., Hanušová, S., Kostková, K., Janíková, V., Najvar, P., \& Tůma, F. (2013). Učitel expert: jeho charakteristiky a determinanty profesního rozvoje (na pozadí výuky cizích jazyků). Brno: MU. 
Pollard, A. (1982). A model of classroom coping strategies. British Journal of Sociology of Education, 3(1), 19-37.

Priestley, M., Biesta, G., \& Robinson, S. (2015). Teacher agency: An ecological approach. London: Bloomsbury Publishing.

Secretan, L. H. K. (1999). Inspirational leadership. Toronto: MacMillian Canada.

Vähäsantanen, K., Paloniemi, S., Hökkä, P., \& Eteläpelto, A. (2017). Agentic perspective on fostering work-related learning. Studies in Continuing Education, 39(3), 1-16.

Walterová, E. (2016). Možnosti a limity sítování se zřetelem k pedagogickému výzkumu. Pedagogika, 66(5), 511-529.

Yinon, H., \& Orland-Barak, L. (2017). Career stories of Izraeli teachers who left teaching: a salutogenic view of teacher attrition. Teachers and Teaching: Theory and Practice, 23(3), $1-14$.

doc. PhDr. Michaela Píšová, M. A., Ph.D., Institut výzkumu školního vzdělávání Pedagogická fakulta, Masarykova univerzita

Poŕíćí 9, 60300 Brno pisova.mich@gmail.com

doc. Mgr. Světlana Hanušová, Ph.D., katedra anglického jazyka a literatury Pedagogická fakulta, Masarykova univerzita Pořićí 9, 60300 Brno hanusova@ped.muni.cz 